\title{
INFLUENCE OF BETAMETHASONE DIPROPIONATE AND PREDNISONE ON ENZYME KINETICS
}

\author{
SAFIJA HERENDA ${ }^{1 *}$, MIRSAD CRNKIĆ ${ }^{1}$, LEJLA KLEPO ${ }^{1}$, EDHEM HASKOVIĆ ${ }^{2}$, DENIS \\ HASKOVIĆ ${ }^{3}$, ENA DELJKIĆ ${ }^{4}$ \\ ${ }^{1}$ Department of Chemistry, Faculty of Science, University of Sarajevo, Sarajevo, Bosnia and Herzegovina \\ ${ }^{2}$ Department of Biology, Faculty of Science, University of Sarajevo, Sarajevo, Bosnia and Herzegovina \\ ${ }^{3}$ Clinical Center of the University of Sarajevo Organizational unit clinical pathology, cytology and human genetics, Sarajevo, \\ Bosnia and Herzegovina \\ ${ }^{4}$ Clinical Center of the University of Sarajevo, Organizational unit clinical biochemistry with immunology, Sarajevo, Bosnia \\ and Herzegovina
}

*corresponding author: islamovic.safija@gmail.com

Manuscript received: March 2021

\begin{abstract}
Most pharmaceutical and nutritional compounds are marketed as enzyme inhibitors, and such inhibitors show their specific action in inhibiting enzymes within cells. Since their discovery, corticosteroid treatment has been one of the most used and effective treatments for various inflammatory and autoimmune disorders. Corticosteroids have anti-inflammatory and immunosuppressive effects, so it is hypothesized that these corticosteroids will have an inhibitory effect on the enzyme catalase. This study aimed to examine the effect of the corticosteroid's betamethasone dipropionate and prednisone on catalase activity in vitro. A spectrophotometric method was used based on the reaction between hydrogen peroxide, enzymes, and corticosteroids. After incubation at $37^{\circ} \mathrm{C}$ with the addition of ammonium heptamolybdate, a stable complex was formed, and the absorbances were analysed. The obtained results indicate an uncompetitive type of inhibition in betamethasone dipropionate, while prednisone acts as a partial competitive agent.
\end{abstract}

\section{Rezumat}

Majoritatea compușilor farmaceutici și nutraceutici sunt comercializați ca inhibitori de enzime, acționând din interiorul celulelor. De la descoperirea lor, tratamentul cu corticosteroizi a fost unul dintre cele mai frecvent utilizate şi mai eficiente tratamente pentru diferite afecțiuni inflamatorii și autoimune. Corticosteroizii au efecte antiinflamatorii și imunosupresoare, deci vor avea un efect inhibitor asupra catalazei. Acest studiu și-a propus să examineze efectul corticosteroizilor betametazonă dipropionat și prednison asupra activității catalazei in vitro. A fost utilizată o metodă spectrofotometrică bazată pe reacția dintre peroxidul de hidrogen, enzime și corticosteroizi. După incubarea la $37^{\circ} \mathrm{C}$ și adăugarea de heptamolibdat de amoniu, s-a format un complex stabil şi au fost înregistrate absorbanțele. Rezultatele obținute indică un tip necompetitiv de inhibiție în cazul dipropionatului de betametazonă, în timp ce prednisonul acționează ca un agent inhibitor competitiv parțial.

Keywords: glucocorticoids, catalase, enzyme inhibition, spectrophotometry

\section{Introduction}

The enzyme shows specific activity and binding affinity with its substrate to complete the enzymatic or biocatalytic reaction. Substrate analogues can inhibit the enzyme reaction and act as an enzyme inhibitor. Enzyme inhibition occurs when a specific substrate or enzyme inhibitor reduces or blocks the action of an enzyme on a specific region of the enzyme's active site. The action of enzyme inhibitors in drug detection has become a fundamental approach in pharmacology in any pharmaceutical industry, university research laboratory, or drug research centre [1]. Corticosteroid treatment is one of the most commonly used and effective treatments for various inflammatory and autoimmune disorders. They are used as replacement therapy in adrenal insufficiency, as well as in physiological doses for the management of various dermatological, ophthalmological, rheumatological, pulmonary or haematological disorders [2]. Corticosteroids are natural biomolecules produced in the adrenal cortex and have a multitude (multiple) of roles that include: metabolism of carbohydrates, proteins, and fats, inflammation, regulation of water and electrolytes, etc. Based on their functions, steroids are classified as glucocorticoids and mineralocorticoids.

Glucocorticoids (GC) are the primary stress hormones that regulate an important number of physiological processes and are released from the adrenal cortex. At the cellular level, glucocorticoids are maintained with specific metabolic enzymes such as $11 \beta$-hydroxysteroid dehydrogenase (11 $\beta$-HSD). 11 $\beta$-HSD catalyses the interconversion of active glucocorticoids, while $11 \beta$-HSD2 functions as a dehydrogenase that rapidly inactivates glucocorticoids (converts cortisol to cortisone), 
allowing the selective approach of aldosterone, which is otherwise a nonselective mineralocorticoid receptor in the kidney and pancreas [3]. Mineralocorticoids affect the transport of ions in the epithelium of renal tubular cells and are involved in the regulation of electrolyte and water balance [4]. Endogenous GCs affect biological processes, including growth, metabolism, development, immune function, and stress response. Unlike endogenous glucocorticoids, most synthetic glucocorticoids do not bind to corticosteroid-binding globulin (CBG) and are not metabolized by $11 \beta$ HSD2. However, 11 -HSD1 acts as the dominant $11 \beta$-reductase in all target glucocorticoid tissues such as liver, adipose tissue, brain, and lung and facilitates the conversion of an inactive cortisone precursor to bioactive cortisol [5]. Glucocorticoids and derived drugs (called corticosteroids) are widely used as pharmacological agents to treat pneumonia, asthma, and immunological/rheumatic diseases. Betamethasone dipropionate $\left(\mathrm{C}_{28} \mathrm{H}_{37} \mathrm{FO}_{7}\right)$ is a synthetic glucocorticoid, a derivative of prednisone, $16 \beta$-methylprednisone, which has immunosuppressive and anti-inflammatory properties. Based on its potency, betamethasone dipropionate belongs to the first group of super potent corticosteroids. The classifications of individual drugs are not so precise because, depending on the study, the groups of particular corticosteroids differ. Thus, based on the second classification, betamethasone dipropionate belongs to the third group, or moderately potent corticosteroids [6]. It is most often present in a topical form with a concentration of $0.05 \%$. Betamethasone dipropionate is used in the treatment of various skin diseases. It is generally most effective in acute or chronic dermatoses (e.g. seborrheic or atopic dermatitis, localized neurodermatitis, psoriasis, late-phase allergic contact dermatitis, inflammatory phase xerosis).

Prednisone $\left(\mathrm{C}_{21} \mathrm{H}_{26} \mathrm{O}_{5}\right)$ is a synthetic, anti-inflammatory glucocorticoid, a derivative of prednisolone, specifically 11-keto prednisolone [6]. It is biologically inert and manifests its effects only when converted to prednisolone in the liver.

Prednisone is used as an anti-inflammatory or immunosuppressive agent to treat a wide range of diseases, including immunosuppressive/endocrine, rheumatic, dermatological, allergic, ocular, respiratory, neoplastic, haematological, oedematous, gastrointestinal (acute exacerbations of multiple sclerosis), and as an antiinflammatory agent. It acts on the immune system to relieve swelling, redness, itching and allergic reactions. It is most commonly administered orally in the form of tablets in a concentration range of $1 \mathrm{mg}$ to $20 \mathrm{mg}$. After binding to receptors on the cell surface and entering the cell, prednisone enters the nucleus, where it binds and activates specific receptors, leading to altered gene expression and inhibition of proinflammatory cytokine production. This agent reduces circulating lymphocytes, induces cell differentiation, and stimulates apoptosis in susceptible populations of tumour cells [7].
Patients on long-term glucocorticoid therapy may develop specific glucocorticoid resistance. Understanding the molecular mechanisms on which the physiological and pharmacological action of glucocorticoids is of great importance because it can help develop synthetic glucocorticoids with increased tissue selectivity [8]. The main objective of the study is to examine the effect of the corticosteroids betamethasone dipropionate and prednisone on catalase activity in vitro. Catalase was chosen for research because it belongs to the group of oxidoreductases that catalyse the decomposition of hydrogen peroxide into molecular oxygen and water without producing free radicals. Also, catalase is involved in functions such as protection against reactive oxygen species (ROS) generated by metabolic processes.

\section{Materials and Methods}

Chemicals (reagents): Hydrogen peroxide, $30 \%$ w/w, Sigma-Aldrich; Bovine liver catalase enzyme, aqueous solution, c100-50 MG, Sigma-Aldrich; Ammonium heptamolybdate, Sigma-Aldrich; Phosphate buffer, $\mathrm{KH}_{2} \mathrm{PO}_{4}$, and $\mathrm{Na}_{2} \mathrm{HPO}_{4}$, Fisher Chemical (Wien, Austria); Betamethasone dipropionate, Bosnalijek, BiH; Prednisone tablets, $10 \mathrm{mg}$, Spain.

Method: The spectrophotometric method in the presence of ammonium heptamolybdate, described in the Góth literature [9], was used. Using kinetic laws, the obtained absorbances were translated into appropriate velocities. To examine the type of inhibitory effect of different concentrations of betamethasone dipropionate (25.36 $\mu \mathrm{M}$ and $33.81 \mu \mathrm{M})$ in the range of hydrogen peroxide substrate concentrations $(1.5-2.5 \mathrm{mM})$ on enzyme activity, the Michaelis-Menten kinetic model was used. Using the Lineweaver-Burk equation, the kinetic parameters, the constants $\mathrm{K}_{\mathrm{m}}$ and $\mathrm{V}_{\max }$, can be calculated for the corresponding concentrations of betamethasone dipropionate $[10,11]$ :

$$
\frac{1}{v_{0}}=\frac{K_{m}}{V_{\max }} \frac{1}{S}+\frac{1}{V_{\max }}\left(1+\frac{[I]}{K_{i}}\right)
$$

Based on the obtained directions and their mutual arrangement in the Cartesian coordinate system, it is possible to determine the type of inhibition in the observed system. To confirm with certainty what type of inhibition it is, the research results also used Dixon's diagram to interpret the obtained results. Using the Dixon diagram, in contrast to the Lineweaver-Burk diagram, the effect of different substrate concentrations on the enzyme/inhibitor system is observed [12, 13]. Based on the presented Dixon equation, the constants $\mathrm{K}_{\mathrm{m}}$ and $\mathrm{V}_{\max }$ can be calculated for the corresponding concentrations of betamethasone dipropionate:

$$
\frac{1}{v}=\frac{1}{V_{\max }}\left(1+\frac{K_{m}}{[S]}\right)+\frac{[I]}{V_{\max } \cdot K_{\text {iu }}}
$$

By determining the kinetic parameters of enzyme inhibition, only the type of inhibitory activity of prednisone and betamethasone dipropionate was evaluated. 
To assess the efficiency of these drugs, it is necessary to calculate the $\mathrm{IC}_{50}$ value for individual substrate concentrations. $\mathrm{IC}_{50}$ is a measure of effectiveness in inhibiting specific biological or biochemical functions. It tells us how much drug is needed to inhibit half of the biological process $[14,15]$.

\section{Results and Discussion}

The linear relationships of these two parameters were determined by graphing the reciprocal values of substrate concentrations on the abscissa and the reciprocal values of enzymatic reaction rates. This further allows the Michaelis-Menten constant and the maximum reaction rate to be calculated based on the Lineweaver-Burk diagram Figure 1, Table I.

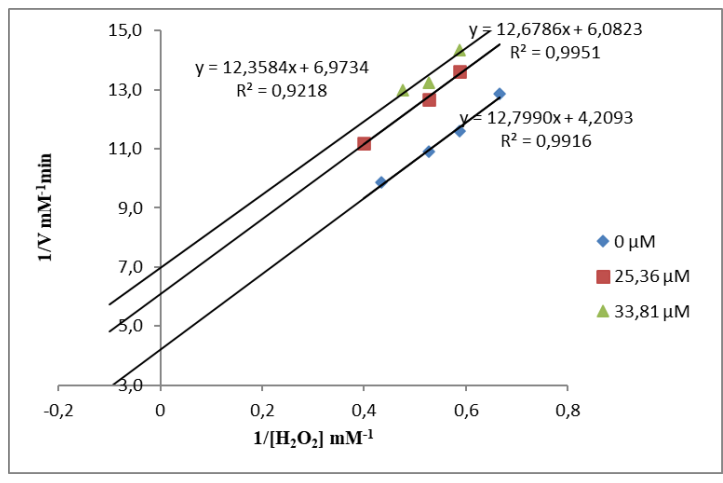

Figure 1.

Lineweaver - Burk diagram for determination of Vmax and Km without the presence and with the presence of different concentrations of betamethasone dipropionate

Table I

$\mathrm{K}_{\mathrm{m}}$ and $\mathrm{V}_{\max }$ values without the presence and with the presence of different concentrations of betamethasone dipropionate

\begin{tabular}{|c|c|c|}
\hline [betamethasone] $(\mu \mathrm{M})$ & $\mathrm{V}_{\max }(\mathrm{mM} / \mathrm{min})$ & $\mathrm{K}_{\mathrm{m}}(\mathrm{mM})$ \\
\hline 0 & 0.2376 & 3.0406 \\
\hline 25.36 & 0.1644 & 2.0845 \\
\hline 33.81 & 0.1434 & 1.7722 \\
\hline
\end{tabular}

Based on the graphical presentation of the effects of betamethasone dipropionate, it is obvious that it is a competitive type of enzyme inhibition, which is indicated by parallel directions and constant slopes for each concentration of inhibitor Figure 1. Inhibitors of this modality require the prior formation of ES binding and inhibition complexes. Therefore, these inhibitors affect the catalysis steps after the initial non-covalent binding of the substrate to the active site of the enzyme [16].

In the first step of the mechanism, the substrate binds to the enzyme's active site, and then betamethasone binds to the ES complex to form the enzyme-substrateglucocorticoid complex (ESI). The betamethasone intermediate occurs when stereospecific hydride electron transfer occurs from the substrate to the glucosteroid double bond. This enolate intermediate is stabilized by interaction with an acid group within the enzyme active site. Then comes the donation of protons from the active site to enolate carbon, forming the reaction product $[17,18]$. The Dixon diagram confirmed another proof that this is the uncompetitive type of inhibition. Table II, Figure 2. The Dixon diagram is used to determine and distinguish complete from partial inhibitions.

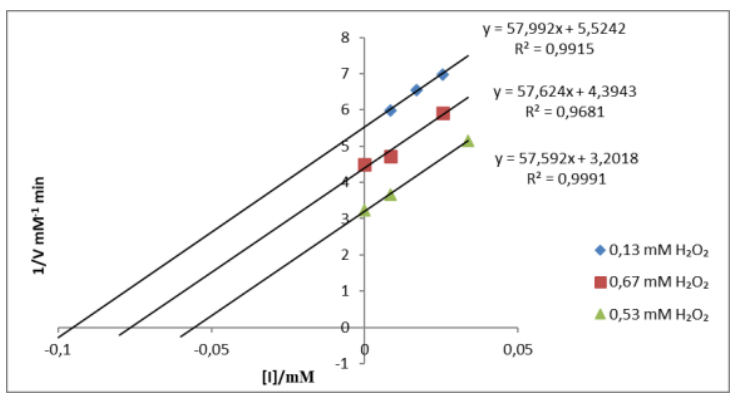

Figure 2.

Dixon diagram for determination of $\mathrm{V}_{\max }$ and $\mathrm{K}_{\mathrm{m}}$ with the presence of different concentrations of betamethasone dipropionate

As the concentrations of betamethasone dipropionate increase in the observed system, the values of the constants $\mathrm{V}_{\max }$ and $\mathrm{K}_{\mathrm{m}}$ change, this indicates that this is the uncompetitive type of inhibition (Table II).

Table II $\mathrm{K}_{\mathrm{m}}$ and $\mathrm{V}_{\max }$ values from the Dixon diagram without the presence and with the presence of different concentrations of $\mathrm{H}_{2} \mathrm{O}_{2}$

\begin{tabular}{|c|c|c|}
\hline$\left[\mathrm{H}_{2} \mathrm{O}_{2}\right] \mathrm{mM}$ & $\mathrm{V}_{\max }(\mathrm{mM} / \mathrm{min})$ & $\mathrm{K}_{\mathrm{m}}(\mathrm{mM})$ \\
\hline 0.13 & 0.01724 & 0.09523 \\
\hline 0.53 & 0.01735 & 0.07624 \\
\hline 0.67 & 0.01736 & 0.05558 \\
\hline
\end{tabular}

Based on this evidence of the inhibitory properties of glucocorticoids, it can be concluded that synthetic derivatives of these molecules can be used to treat inflammatory disorders, autoimmune diseases, and haematological cancers. However, the action of glucocorticoids in the treatment of inflammatory and immune disorders is limited due to the occurrence of various side effects during high-dose treatment. These accompanying symptoms are diabetes, poorly healed wound, skin atrophy, muscle atrophy, hypertension, metabolic syndrome, osteoporosis and water/electrolyte imbalance [19]. In the last few decades, research has been done on modifying the chemical structure of natural glucocorticoids to reduce side effects. They found that multiple glucocorticoid receptors with a unique expression, gene regulation, and functional profile generate alternative mRNA binding and initiation, allowing an understanding of the molecular basis of glucocorticoid sensitivity (hyposensitivity or hypersensitivity) [20]. In addition to testing trials of 
betamethasone dipropionate inhibitors, we investigated and influenced different concentrations of prednisone on catalase activity (Figure 3, Table III).

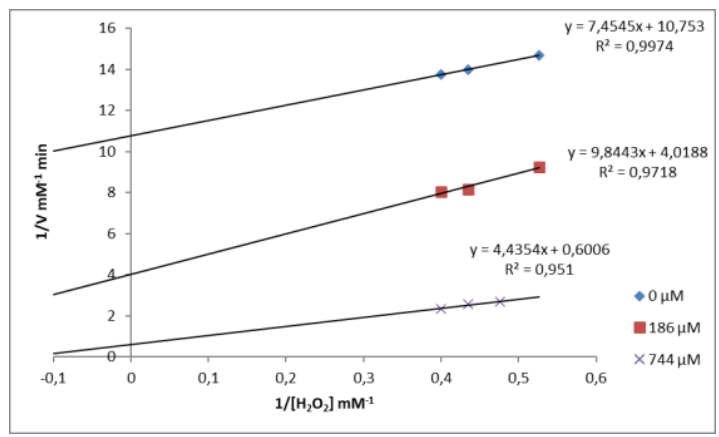

Figure 3.

Lineweaver - Burk diagram for the determination of $\mathrm{V}_{\max }$ and $\mathrm{K}_{\mathrm{m}}$ without the presence and with the presence of different concentrations of prednisone

\section{Table III}

$\mathrm{K}_{\mathrm{m}}$ and $\mathrm{V}_{\max }$ values without the presence and with the presence of different prednisone concentrations

\begin{tabular}{|c|c|c|}
\hline [prednisone] $\mu \mathrm{M}$ & $\mathrm{V}_{\max }(\mathrm{mM} / \mathrm{min})$ & $\mathrm{K}_{\mathrm{m}}(\mathrm{mM})$ \\
\hline 0 & 0.0930 & 0.6932 \\
\hline 186 & 0.2488 & 2.4496 \\
\hline 744 & 1.6650 & 7.3849 \\
\hline
\end{tabular}

Based on the values obtained, it is concluded that prednisone has a partially uncompetitive inhibitory effect on catalase activity [21].

Partial inhibition of catalase suggests that degradation partially continues even after prednisone has inhibited the enzyme-substrate complex and formed enzymesubstrate-inhibitor partially dissociates on the enzyme, the product, and inhibitor [22]. Prednisone tablets, in addition to the active substance, also contain the following auxiliary components: lactose monohydrate, magnesium stearate, microcrystalline cellulose, pregelatinized starch, sodium starch glycolate. Depending on the manufacturer, other components are also present, such as stearic acid (emulsifying agent, solubilizing agent, lubricant for tablets and capsules) and propyl hydroxybenzoate [23]. Auxiliary components present in tablets such as prednisone, which may interfere with the inhibition mechanism itself or reduce the effect of the inhibitor itself, are likely to be of some importance for this type of mechanism. Prednisone was not available in pure form as an active ingredient in tablet form. Due to the relatively low solubility in water, the tablet had to be dissolved in an organic solvent such as DMSO. Auxiliary components, including starch, mostly influenced solubility in water. Due to its high molecular weight and the long chains, it forms, starch is difficult to dissolve in an aqueous medium. The water molecules that enter the starch particles lead to the expansion of the chains and their gradual branching and crosslinking, leaving the dry starch trapped in the centre, leading to the impossibility of complete dissolution in the water. Polar aprotic solvents such as dimethyl sulfoxide (DMSO) are probably the most commonly used starch solvent, especially in the form of a DMSO aqueous solution $\left(10 \% \mathrm{H}_{2} \mathrm{O} 90 \%\right.$ DMSO) $[24,25]$. It is known that organic solvents affect enzymes, with a particular affinity depending on their structure and concentration. The effect of primarily DMSO on catalase was investigated using fluorimetric and CD measurements. Fluorimetric spectra of catalase in the presence of DMSO indicate an increase in fluorescence as well as a redshift, which means that the unwinding of the enzyme molecule has occurred. The far UV-CD spectrum indicating secondary catalase structures show certain maxima depending on the type of organic solvent. The far and near UV-CD spectra differ from the base spectra without the presence of an organic solvent, indicating that the tertiary and secondary structure of the enzyme was partially disrupted. Increasing the proportion of organic solvent also reduces the percentage of catalase activity. It can be concluded with certainty that the kinetic parameters will significantly depend on the type and amount of organic solvent, DMSO. Changes in the structure of proteins induced by chemical or physical agents are usually associated with partial or complete loss of biological activity, as indicated by the results of this study [26]. Table IV shows the $\mathrm{IC}_{50 \%}$ value of betamethasone dipropionate inhibition on catalase activity because it is a pure active component of the drug.

The results indicate a correlation between the influence of betamethasone dipropionate concentration on catalase activity or IC50\% value. At low substrate concentrations, $0.13 \mathrm{mM} \mathrm{H}_{2} \mathrm{O}_{2}$, the enzyme inhibition percentages were $30.15 \%, 36.22 \%$ and $39.98 \%$ for betamethasone dipropionate concentrations of $8.45 \mathrm{mM}, 16.91 \mathrm{mM}$, and $25.36 \mathrm{mM}$, respectively. Betamethasone dipropionate contains two fluorine atoms in its structure.

Table IV

Percentage of catalase inhibition for different concentrations of betamethasone dipropionate

\begin{tabular}{|c|c|c|c|c|}
\hline$\left[\mathrm{H}_{2} \mathrm{O}_{2}\right] \mathrm{mM}$ & [betamethasone] $\mu \mathrm{M}$ & $\mathrm{A}_{0}$ & $\mathrm{~A}_{\mathrm{i}}$ & $\%$ inhibition \\
\hline \multirow{3}{*}{0.13} & 8.45 & \multirow{3}{*}{0.2391} & 0.1670 & 30.1547 \\
\hline & 16.91 & & 0.1525 & 36.2192 \\
\hline & 25.36 & & 0.1435 & 39.9833 \\
\hline \multirow{3}{*}{0.53} & 8.45 & \multirow{3}{*}{0.2245} & 0.1521 & 32.2494 \\
\hline & 16.91 & & 0.1469 & 34.6570 \\
\hline & 25.36 & & 0.1362 & 39.3318 \\
\hline
\end{tabular}


FARMACIA, 2021, Vol. 69, 6

\begin{tabular}{|c|c|c|c|c|}
\hline 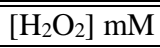 & ["betamethasone] $\mu \mathrm{M}$ & $\mathrm{A}_{0}$ & $\mathrm{~A}_{\mathrm{i}}$ & \% inhibition \\
\hline \multirow{4}{*}{0.67} & 8.45 & \multirow{4}{*}{0.3099} & 0.2115 & 34.0711 \\
\hline & 16.91 & & 0.2030 & 36.7207 \\
\hline & 25.36 & & 0.1693 & 47.2257 \\
\hline & 33.81 & & 0.1497 & 53.3354 \\
\hline \multirow{4}{*}{1.50} & 8.45 & \multirow{4}{*}{0.0992} & 0.0841 & 15.2218 \\
\hline & 16.91 & & 0.0807 & 18.6492 \\
\hline & 25.36 & & 0.0825 & 16.8347 \\
\hline & 33.81 & & 0.0742 & 25.2016 \\
\hline \multirow{4}{*}{1.90} & 8.45 & \multirow{4}{*}{0.0981} & 0.0801 & 18.3486 \\
\hline & 16.91 & & 0.0783 & 20.1835 \\
\hline & 25.36 & & 0.0753 & 23.2416 \\
\hline & 33.81 & & 0.0755 & 23.0377 \\
\hline
\end{tabular}

Inhibition of enzymes and regulatory proteins by fluorides can be an important physiological factor for the work of the organism, e.g. macrophages, primarily if they are present for a long time [27, 28]. As the substrate concentration and the drug concentration increase, the percentage of inhibition also increases. At very high substrate concentrations higher than 1.5 $\mathrm{mM}$, a sharp decrease in the inhibitory effect on the enzyme is observed. A possible reason for this behaviour of the system is the oversaturation of the enzyme with the substrate and the impossibility of adequate binding of betamethasone dipropionate to the active sites of the enzyme. Under in vivo conditions, 80 - 90\% of glucocorticoids bind to corticosteroid-binding globulin (CBG) and $5-15 \%$ are bound to albumin to keep most glucocorticoids in an inactive form. Only $5 \%$ of systemic glucocorticoids are free and bioactive [29]. At optimal $\mathrm{pH}$ of 7 and a temperature of $37^{\circ} \mathrm{C}$, the catalase activity is lower the higher the concentration of fluoride or betamethasone dipropionate. For a living organism, this means more hydrogen peroxide and a higher probability of developing free radicals and damaging the organism. This conclusion is supported by the fact that long-term use of corticosteroids leads to various side effects, often and more severe forms of the disease, which were primarily treated with this type of drug. The immunosuppressive properties of corticosteroids can lead to infections by bacteria that the body could otherwise defend. In addition to severe side effects, corticosteroids successfully treat a variety of skin diseases, including psoriasis, rheumatoid arthritis, and have been shown to increase the effectiveness of treatment in combination with antibiotics $[7,30,31]$.

\section{Conclusions}

Research has shown that the enzyme catalase follows the Michaelis-Menten kinetic model. Based on the graphical presentation of the effect of betamethasone dipropionate, it is obvious that it is an uncompetitive type of enzyme inhibition. Betamethasone dipropionate inhibits catalase in vitro and affects its activity at different concentrations, which indicates that at the tested concentrations of the substrate it exhibits improved anti-inflammatory activity. In contrast to the pure active component assay, the LineweaverBurk diagram for prednisone suggests partial competitive competition. At a temperature of $37^{\circ} \mathrm{C}$ and a $\mathrm{pH}$ value of 7, optimal conditions for conducting research were achieved. The highest inhibition percentage of $53.33 \%$ was obtained at a concentration of betamethasone of $33.81 \mu \mathrm{M}$, which leads to the conclusion that this concentration is sufficient in the successful treatment of various skin diseases. A kinetic understanding of the binding of glucocorticoids to enzymes will help develop safer and more effective glucocorticoid therapies.

\section{Conflict of interest}

The authors declare no conflict of interest.

\section{References}

1. Copeland RA, Evaluation of Enzyme Inhibitors in Drug Discovery, Hoboken: John Wiley \& Sons, Inc., 2005.

2. Liu D, Ahmet A, Ward L, Krishnamoorthy P, Mandelcorn ED, Leigh R, Kim HA, A practical guide to the monitoring and management of the complications of systemic corticosteroid therapy. Allergy Asthma Clin Immunol., 2013; 9(1): 30: 1-15.

3. Seckl JR, 11beta-hydroxysteroid dehydrogenases: changing glucocorticoid action. Curr Opin Pharmacol., 2004; 4: 597-602.

4. Eapen MS, Shukla SD, Mahmood MQ, McAlindenVolkovickas K, Eri RD, Walters EH, Sohal SS, Role of Corticosteroids in Chronic Obstructive Pulmonary Disease (COPD). In Corticosteroids and Steroid Therapy, Adkins C; New York: Nova Science Publishers, Inc, 2015.

5. Cooper MS, Stewart PM, 11Beta-hydroxysteroid dehydrogenase type 1 and its role in the hypothalamuspituitary-adrenal axis, metabolic syndrome, and inflammation. J Clin Endocrinol Metab., 2009; 94: 4645-4654.

6. Brazzini B, Pimpinelli N, New and established topical corticosteroids in dermatology. Am J Clin Dermatol., 2002; 3(1) :47-58.

7. Conn DL, Resolved: Low-dose prednisone is indicated as a standard treatment in patients with rheumatoid arthritis. Arthritis Rheum., 2001; 45(5): 462-467.

8. Barnes PJ, Mechanisms and resistance in glucocorticoid control of inflammation. J Steroid Biochem Mol Biol., 2010; 120:76-85. 
9. Góth L, A simple method for determination of serumcatalase activity and revision of reference range. Clinica Chemica Acta.,1991; 196 (2-3): 143-151

10. Michaelis L, Menten ML, Die Kinetik der Invertinwirkung. Biochem Z.,1913; 49: 333-369.

11. Markus M, Hess B, Ottaway JH, Cornish-Bowden A, The analysis of kinetic data in biochemistry. A critical evaluation of methods. FEBS Lett., 1976; 63: 225-230.

12. Dixon $\mathrm{M}$, The determination of the enzyme inhibition constants. Biochem J., 1953; 55: 170-171.

13. Dixon M, The graphical determination of $\mathrm{Km}$ and Ki. Biochem J., 1972; 129:197-202.

14. Bisswanger H, Enzyme Kinetics.Weinheim: WileyVCH Verlag GmbH \& Co. KgaA, 2017.

15. Copeland RA, Mechanistic considerations in highthroughput screening. Anal Biochem., 2003; 320(1): $1-12$.

16. Marangoni AG, Enzyme kinetics: a modern approach. John Wiley \& Sons, Inc., Hoboken, New Jersey. 2003.

17. Schramm VL, Enzymatic transition states and transition state analogs. Curr Opin Struct Biol., 2005;15, 604613.

18. Copeland RA, Anderson PS, Enzymes and Enzyme Inhibitors. In Textbook of Drug Design and Discovery, $3^{\text {rd }}$ ed., Krogsgaard-Larsen P, Liljefors T, Madsen U, eds., Taylor and Francis, New York, 2001: 328-363.

19. Ramamoorthy S, Cidlowski JA, CorticosteroidsMechanisms of Action in Health and Disease. Rheum Dis Clin North Am., 2016; 42(1): 15-31.

20. Clark AR, Belvisi MG, Maps and legends: the quest for dissociated ligands of the glucocorticoid receptor. Pharmacol Ther., 2012; 134: 54-67.

21. Whiteley CG, Enzyme kinetics: partial and complete uncompetitive inhibition. Biochem Educ., 2000; 28(3): 144-147.

22. Park JH, Yoo IK, Kwon OY, Ryu K, Partial uncompetitive inhibition of horseradish peroxidase by a water-miscible ionic liquid [BMIM] $\left[\mathrm{MeSO}_{4}\right]$. Biotechnol Lett., 2011; 33(8): 1657-1662.
23. Kalász H, Antal I, Drug excipients. Curr Med Chem., 2006; 13(21): 2535-2563.

24. Szwengiel A, Lewandowicz G, Nowak J, Advantages and disadvantages of the use of aqueous and organic GPC columns for the separation of starch macromolecules. $12^{\text {th }}$ International Conference on PolysaccharidesGlycoscience, 2016; 6: 71-76.

25. Rehan M, Younus H. Effect of organic solvents on the conformation and interaction of catalase and anticatalase antibodies. Int J Biol Macromol., 2006; 38(3-5): 289295.

26. Dumitraşcu PA, Funieru C, Anuța V, Coman AG, Alecsandrescu C, Ivancencu A, Popa L, Ghica MV, Dinu-Pîrvu CE, Evaluation of the impact of the inlet air humidity during coating step on the in vitro dissolution of modified-release film-coated pellets containing a BCS class I active substance. Farmacia, 2020; 68(5): 856-863.

27. Phan TN, Kirsch AM, Marquis RE, Selective sensitization of bacteria to peroxide damage associated with fluoride inhibition of catalase and pseudocatalase. Oral Microbiol Immunol., 2001; 16(1): 28-33.

28. Goschorska M, Gutowska I, Olszewska M, BaranowskaBosiacka I, Rać M, Olszowski T, Chlubek D, Effect of sodium fluoride on the catalase activity in THP-1 macrophages. Fluoride, 2015; 48(4): 274-282.

29. Breuner CW, Orchinik M, Plasma binding proteins as mediators of corticosteroid action invertebrates. $J$ Endocrinol., 2002; 175: 99-112.

30. Uva L, Miguel D, Pinheiro C, Antunes J, Cruz D, Ferreira J, Filipe P, Mechanisms of action of topical corticosteroids in psoriasis. Int J Endocrinol., 2012; 2012: 561018: 1-16

31. Artini M, Papa R, Cellini A, Tilotta M, Barbato G, Koverech A, Selan L, Effect of betamethasone in combination with antibiotics on gram positive and gram negative bacteria. Int J Immunopathol Pharmacol., 2014; 27(4): 675-682. 